DOI: 10.22630/EIOGZ.2014.106.18

Zeszyty Naukowe Szkoły Głównej Gospodarstwa Wiejskiego

Ekonomika i Organizacja Gospodarki Żywnościowej nr 106, 2014: 97-110

Michał Pietrzak

Katedra Ekonomiki i Organizacji Przedsiębiorstw

Szkoła Główna Gospodarstwa Wiejskiego w Warszawie

\title{
Inwestycje w majątek trwały a wyniki ekonomiczno-finansowe spółdzielni mleczarskich
}

\section{Wstęp}

Długookresowa konkurencyjność przedsiębiorstwa, a w konsekwencji możliwość generowania zysków, zależy w dużej mierze od trafności decyzji rozwojowych [Sierpińska, Jachna 1997, s. 189]. Rozwój przedsiębiorstwa interpretuje się najczęściej w kategoriach wzrostu sprzedaży, a ten z kolei uwarunkowany jest przyrostem majątku, który osiaggany jest dzięki podejmowaniu przedsięwzięć inwestycyjnych [Pluta 1999, s. 129]. Podobnie rozwój firmy interpretują również Sierpińska i Jachna [1997, s. 189]. Decyzje inwestycyjne zaliczane są - obok decyzji operacyjnych oraz dotyczących finansowania - do trzech kluczowych kategorii decyzji podejmowanych $\mathrm{w}$ procesie zarządzania finansami przedsiębiorstwa [Jajuga, Jajuga 2006, s. 335]. Przy tym należy się zgodzić z opinią, że decydowanie o kierunkach rozwoju przedsiębiorstwa ,jest jednym z najbardziej interesujących, a jednocześnie najtrudniejszych zadań, szczególnie jeśli rozwój ma być osiagany dzięki przyrostowi majątku" [Pluta 1999, s. 138].

Jak trafnie zauważa Hirshleifer: „Inwestycja jest w istocie bieżącym wyrzeczeniem dla przyszłej korzyści. Jednak teraźniejszość jest względnie dobrze znana, natomiast przyszłość jest tajemnicą. Inwestycja jest zatem wyrzeczeniem się pewnego dla niepewnej korzyści" [cyt. za Jajuga, Jajuga 2006, s. 9]. Sierpińska i Jachna, powołując sie na Gremilleta, proponują następującą klasyfikację przedsięwzięć inwestycyjnych: inwestycje odtworzeniowe, inwestycje modernizacyjne, inwestycje innowacyjne, inwestycje rozwojowe, inwestycje strategiczne, inwestycje dotyczące ustroju społecznego, inwestycje dotyczące interesu 
publicznego. Autorzy ci podkreślają przy tym, że nie wszystkie wymienione przedsięwzięcia przynoszą przedsiębiorstwu bezpośrednie korzyści, np. wynikają z przepisów prawa [Sierpińska, Jachna 1997, s. 189-190]. W innej klasyfikacji wyodrębnia się [Jajuga, Jajuga 2006, s. 15]:

- inwestycje w instrumenty finansowe,

- inwestycje rzeczowe,

- inne rodzaje inwestycji (np. inwestycje w kapitał ludzki).

Ostatni przykład wskazuje na istotny aspekt zarządzania współczesnymi przedsiębiorstwami. Przywołując opinię byłego prezesa amerykańskiej Rezerwy Federalnej - Alana Greenspana, gospodarka amerykańska wzrosła pięciokrotnie (mierzona PKB), ale jej fizyczna masa powiększyła się tylko nieznacznie, a „,koncepcje i idee zastąpiły dziś zasoby fizyczne i wysiłek ludzkich mięśni” [cyt. za Boulton i in. 2001, s. XV]. Udział tzw. wartości nieksięgowej (różnica pomiędzy wartością rynkową a księgową) w kapitalizacji 10 tysięcy amerykańskich spółek wzrósł w latach 1978-1998 z 5 do 72\% [Boulton i in. 2001, s. 11]. Z kolei Becker i inni zauważaja, że w latach 1985-1999 stosunek wartości rynkowej do wartości księgowej spółek objętych indeksem S\&P 500 wzrósł dwukrotnie, z ok. 2,2 do ok. 5,4 [2002, s. 21-22]. Zjawiska te interpretowane są jako symptomy ewolucji „gospodarki węgla i stali” w kierunku ,gospodarki opartej na wiedzy”.

Ewolucja ta nie oznacza jednak, że inwestycje rzeczowe utraciły swoje znaczenie. Jak słusznie bowiem zauważają Boulton i inni - zarówno zasoby materialne i niematerialne, jako potencjalne źródła przyszłych dochodów, stanowią „tworzywo wartości firmy” [2001, s. 11, 22]. Również Kaplan i Norton wskazują, iż zasoby niematerialne nie mają samoistnej wartości, którą można by wyizolować z organizacyjnego kontekstu - ich wartość wyrasta z odpowiedniej kombinacji i „wymieszania” z aktywami materialnymi [Kaplan, Norton 2004, s. 30]. Przy czym istotą inwestycji rzeczowych są zmiany zdolności produkcyjnych i struktury asortymentowej, zmiany jakości produkcji, obniżka kosztów produkcji, a także zmiany w zakresie zaopatrzenia, zbytu, powiązań kooperacyjnych [Sierpińska, Jachna 1993, s. 189; Boulton i in. 2001, s. 23].

Polski przemysł mleczarski jest istotnym elementem polskiego i europejskiego sektora agrobiznesu, o czym świadczą poniższe dane [Pietrzak 2012, s. 2]:

- trzecia pozycja w UE pod względem zatrudnienia (ok. 34 tys. osób),

- $\quad$ siódma pozycja w UE pod względem wartości produkcji (7\% udziału),

- źródło dochodu dla ok. 150 tys. gospodarstw,

- podstawowa gałąź przemysłu spożywczego (ok. 13,5\% udziału),

- produkty mleczarskie to najczęściej kupowane produkty żywnościowe (ok. $15 \%$ udziału w wydatkach).

W toku przemian po 1989 roku w sektorze dokonano znacznych inwestycji, które w olbrzymim stopniu zmodernizowały polskie mleczarstwo i dostosowały 
je do wymogów UE. Problemem branży pozostaje jednakże znaczna nadpodaż mocy produkcyjnych szacowana nawet na $6 \mathrm{mld} 1 \mathrm{w}$ ekwiwalencie mleka [Pietrzak 2012, s. 5-6, 12-13]. W tym kontekście zasadne staje się pytanie o wpływ inwestowania w majątek trwały na efektywność przedsiębiorstw mleczarskich. Inwestycje rzeczowe, oprócz pozytywnych efektów związanych z modernizacją i rozbudową majątku, mogą bowiem potęgować nadwyżkę mocy produkcyjnych w sektorze, co skutkuje nieefektywnym wykorzystaniem aktywów. Ponadto inwestycje w aktywa rzeczowe prowadzą do zwiększenia kosztów stałych i, co za tym idzie, niekorzystnego przesunięcia progu rentowności, a także mogą skutkować innymi negatywnymi konsekwencjami - dlatego przedsięwzięcia takie powinny być podejmowane $\mathrm{w}$ dostatecznie uzasadnionych sytuacjach [Tyran 2004, s. 75].

\section{Metodyka badań}

Celem artykułu jest weryfikacja tezy o pozytywnym wpływie inwestycji w majątek trwały na wyniki ekonomiczno-finansowe polskich spółdzielni mleczarskich. Aby zrealizować przyjęty cel przeprowadzono badania empiryczne $\mathrm{z}$ wykorzystaniem danych zgromadzonych w ramach autorskiego rankingu przygotowanego w ramach XI Forum Spółdzielczości Mleczarskiej w 2013 roku. Ankiety z danymi za 2012 rok nadesłało 20 przedsiębiorstw, w tym 18 spółdzielni mleczarskich (OSM Bochnia, Ciechanowska SM w Ciechanowie, OSM Czarnków, OSM Gostyń, OSM Grodzisk Mazowiecki, OSM Jarocin, OSM Jasienica Rosielna, OSM Koło, SM Lidzbark Welski, SM Mazowsze w Chorzelach, SM Mlekpol w Grajewie, OSM Piątnica, SM Ryki, OSM Siedlce, OSM Sierpc, SM Spomlek w Radzyniu Podlaskim, SSPM Strzelce Krajeńskie, SDM Wieluń) oraz 2 spółki. Spółki te, ze względu na odmienną specyfikę działalności gospodarczej, nie weszły do dalszych badań. W rezultacie badania przeprowadzono na podstawie danych z 18 obiektów.

Model oceny spółdzielni wykorzystywany w rankingu (por. rys. 1) opiera się na koncepcji Balanced Scorecard - BSC (Zrównoważonej Karty Wyników), która należy do coraz bardziej popularnych spośród współczesnych metod pomiaru osiagnięć organizacji [Pietrzak 2007, s. 80]. BSC jest koncepcją Kaplana i Nortona, którzy na początku lat 90 . opracowali narzędzie wielowymiarowego pomiaru i analizy dokonań przedsiębiorstwa. Zgodnie z ideą Kaplana i Nortona, osiagnięcia firmy powinny być mierzone i analizowane w czterech perspektywach: finansowej, klienta, procesów, wiedzy i rozwoju [Kaplan, Norton 2001, s. 27-28]. W modelu oceny rankingowej uwzględniono zmodyfikowaną architekturę BSC opartą na 5 perspektywach: dodano perspektywę dostawców, 
którzy w branży mleczarskiej pełnią szczególnie ważną rolę, a w spółdzielniach mleczarskich są oni również właścicielami, perspektywę wiedzy i rozwoju zastąpiono zaś perspektywą potencjału, która obejmuje również bazę materialną przedsiębiorstwa, podczas gdy perspektywa wiedzy i rozwoju w klasycznej BSC koncentruje się na tzw. kapitale intelektualnym [Pietrzak, Baran 2011, s. 91].

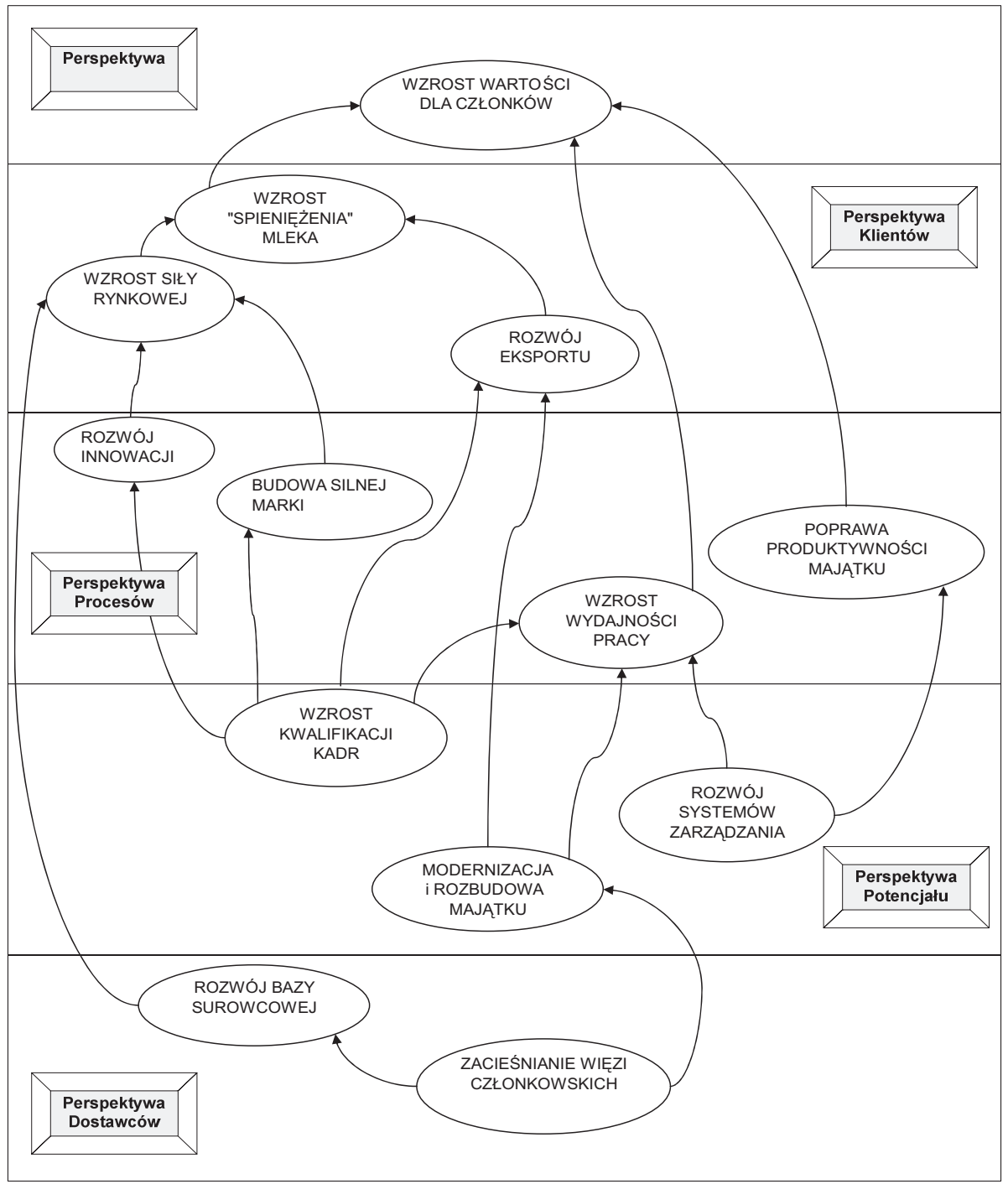

\section{Rysunek 1}

Model oceny rankingowej $w$ formie mapy strategii

Źródło: [Pietrzak, Baran 2011, s. 95]. 
Punktem wyjścia do opracowania Zrównoważonej Karty Wyników jest mapa strategii. Mapę strategii można określić jako formę opisu strategii przedsiębiorstwa bazująca na architekturze BSC (czyli podziale na perspektywy), której zadaniem jest wizualizacja powiązań przyczynowo-skutkowych między celami strategicznymi przedsiębiorstwa. Cele powiązane siecią zależności przyczynowo-skutkowych ujęte $\mathrm{w}$ formie mapy strategii podlegają dalszemu doprecyzowaniu dzięki przyporządkowaniu im mierników osiagnięć [Kaplan, Norton 2004, s. 7-11, 52-53]. Istotę modelu oceny spółdzielni zaprezentowano w formie mapy strategii (rys. 1). Jest to zbiór powiązanych celów w poszczególnych perspektywach. Strzałki łączące cele ilustrują przypuszczenia, co do zależności przyczynowo-skutkowych. Cele odzwierciedlają potencjalny kierunek dążeń spółdzielni pragnącej doskonalić swoje osiągnięcia.

W badaniu prezentowanym $\mathrm{w}$ niniejszym artykule zweryfikowano związek pomiędzy inwestycjami w majątek trwały (cel: ,,modernizacja i rozbudowa majątku" - por. rys. 1) a wynikami ekonomiczno-finansowymi osiemnastu przebadanych spółdzielni. Jako miary inwestycji przyjęto wskaźnik nowoczesności majątku (relacja aktywów trwałych netto ${ }^{1}$ do aktywów trwałych brutto) oraz wskaźniki intensywności inwestowania. W tej drugiej grupie znalazły się wskaźniki będące relacją nakładów inwestycyjnych do: aktywów trwałych brutto, funduszy własnych, przychodów ze sprzedaży, amortyzacji oraz wielkości skupu. Uwzględnionymi miarami wynikowymi były: wskaźnik ekonomicznej wydajności pracy ${ }^{2}$, wskaźnik spieniężenia mleka ${ }^{3}$, stopa zwrotu z kapitału własnego, tj. $\mathrm{ROE}^{4}$, średnioroczna cena skupu mleka netto ${ }^{5}$. Dodatkowo wzięto również pod uwagę siłę więzi członkowskich jako spodziewaną przyczynę wpływającą na cel „modernizacja i rozbudowa majątku”.

W badaniach zastosowano analizę korelacji Pearsona oraz wykresy skategoryzowane. W obliczeniach wykorzystano pakiety MS Excel 2007 oraz STATISTICA 7.1.

\footnotetext{
${ }^{1}$ Czyli z uwzględnieniem odpisów amortyzacyjnych.

2 Według wzoru: przychody ze sprzedaży/zatrudnienie w pełnych etatach [tys. zł/etat].

3 Według wzoru: przychody ze sprzedaży produktów/przerób mleka [zł/l]; Uwaga: dwie z uczestniczących w rankingu spółdzielni miały charakter firm skupowych (brak przerobu mleka) - zamiast przychodów ze sprzedaży produktów uwzględniono w tym wypadku przychody ze sprzedaży towarów i materiałów, a zamiast przerobu - skup mleka.

${ }^{4}$ Według wzoru: (zysk netto/fundusz własny z bilansu zamknięcia) $\times 100 \%[\%]$.

5 Wysoki poziom ceny skupu mleka jest istotną formą transmisji korzyści ekonomicznych do właścicieli spółdzielni - rolników [Pietrzak 2006, s. 82].
} 


\section{Uwarunkowania inwestowania w majątek trwały i skutki ekonomiczno-finansowe tego procesu}

Weryfikując związek inwestycji z wynikami finansowymi wykorzystano model spodziewanych zależności przyczynowo-skutkowych wykorzystywany w rankingu Forum Spółdzielczości Mleczarskiej. Skoncentrowano się na zależnościach związanych z celem „modernizacja i rozbudowa majątku” (por. rys. 1).

W pierwszej kolejności zweryfikowano czy rzeczywiście - jak przewiduje model oceny rankingowej - cel ten jest uwarunkowany siłą więzi członkowskich. Mierząc tę siłę wartością funduszu udziałowego przypadającego na jednego członka spółdzielni, zbadano korelację tego wskaźnika ze zmiennymi przyjętymi za mierniki realizacji celu ,modernizacja i rozbudowa majątku”. Analiza wykazała słabą i nieistotną statystycznie korelację z miernikiem nowoczesności majątku (tj. relacją aktywów trwałych netto do aktywów trwałych brutto). W przypadku większości wskaźników ilustrujących intensywność inwestowania korelacja ta była silna lub średnia oraz istotna statystycznie (tab. 1). Dla zmiennej ilustrującej inwestycje w majątek trwały, wykazującej najsilniejszą korelację z siłą więzi członkowskich, sporządzono dodatkowo wykres skategoryzowany (rys. 2).

Granicą rozdzielającą lewą i prawą stronę rysunku 2 jest mediana wskaźnika fundusz udziałowy na członka spółdzielni. Wyraźnie widać, że w spółdzielniach, w których wskaźnik ten przekracza medianę, tj. 7 tys. złotych na członka,

\section{Tabela 1}

Więzi członkowskie a modernizacja i rozbudowa majątku - współczynniki korelacji Pearsona pomiędzy wskaźnikami

\begin{tabular}{|l|c|c|c|c|c|c|}
\hline \multirow{2}{*}{} & \multicolumn{7}{|c|}{ Zmienne objaśniane } \\
\cline { 2 - 7 } & $\begin{array}{c}\text { Relacja } \\
\text { aktywów } \\
\text { objaśniająca }\end{array}$ & $\begin{array}{c}\text { Nakłady } \\
\text { trwałych } \\
\text { inwestycyjne } \\
\text { netto do } \\
\text { aktywów } \\
\text { trwałych } \\
\text { brutto } \\
\text { aktywówi do } \\
\text { trwałych } \\
\text { brutto }\end{array}$ & $\begin{array}{c}\text { Nakłady } \\
\text { inwestycyjne } \\
\text { w relacji do } \\
\text { funduszy } \\
\text { własnych }\end{array}$ & $\begin{array}{c}\text { Nakłady } \\
\text { inwesty- } \\
\text { cyjne } \\
\text { w relacji } \\
\text { do amorty- } \\
\text { zacji }\end{array}$ & $\begin{array}{c}\text { Nakłady in- } \\
\text { westycyjne } \\
\text { w relacji do } \\
\text { przychodów } \\
\text { ze sprze- } \\
\text { daży }\end{array}$ & $\begin{array}{c}\text { Nakłady } \\
\text { inwesty- } \\
\text { cyjne } \\
\text { w przeli- } \\
\text { czeniu na } \\
\text { litr skupu }\end{array}$ \\
\hline $\begin{array}{l}\text { Fundusz } \\
\text { udziałowy } \\
\text { na członka }\end{array}$ & $\begin{array}{c}0,33 \\
(\mathrm{n}=18)\end{array}$ & $\begin{array}{c}0,30 \\
(\mathrm{n}=16)\end{array}$ & $\begin{array}{c}0,60^{*} \\
(\mathrm{n}=16)\end{array}$ & $\begin{array}{c}0,73^{*} \\
(\mathrm{n}=16)\end{array}$ & $\begin{array}{c}0,46^{* *} \\
(\mathrm{n}=16)\end{array}$ & $\begin{array}{c}0,81^{*} \\
(\mathrm{n}=16)\end{array}$ \\
\hline
\end{tabular}

Uwaga: * korelacje istotne statystycznie na poziomie $\alpha=0,05 ;{ }^{* *}-$ korelacje istotne statystycznie na poziomie $\alpha=0,10$ (braki danych usuwano przypadkami).

Źródło: Badania własne. 
intensywność inwestowania jest znacznie wyższa. Pomijając odstające obiekty - najniższa wartość nakładów inwestycyjnych w przeliczeniu na litr skupionego mleka (tj. $4 \mathrm{gr} / \mathrm{l}$ ) w spółdzielniach o silnych więziach członkowskich odpowiada najwyższej intensywności inwestowania w spółdzielniach o słabych więziach członkowskich.

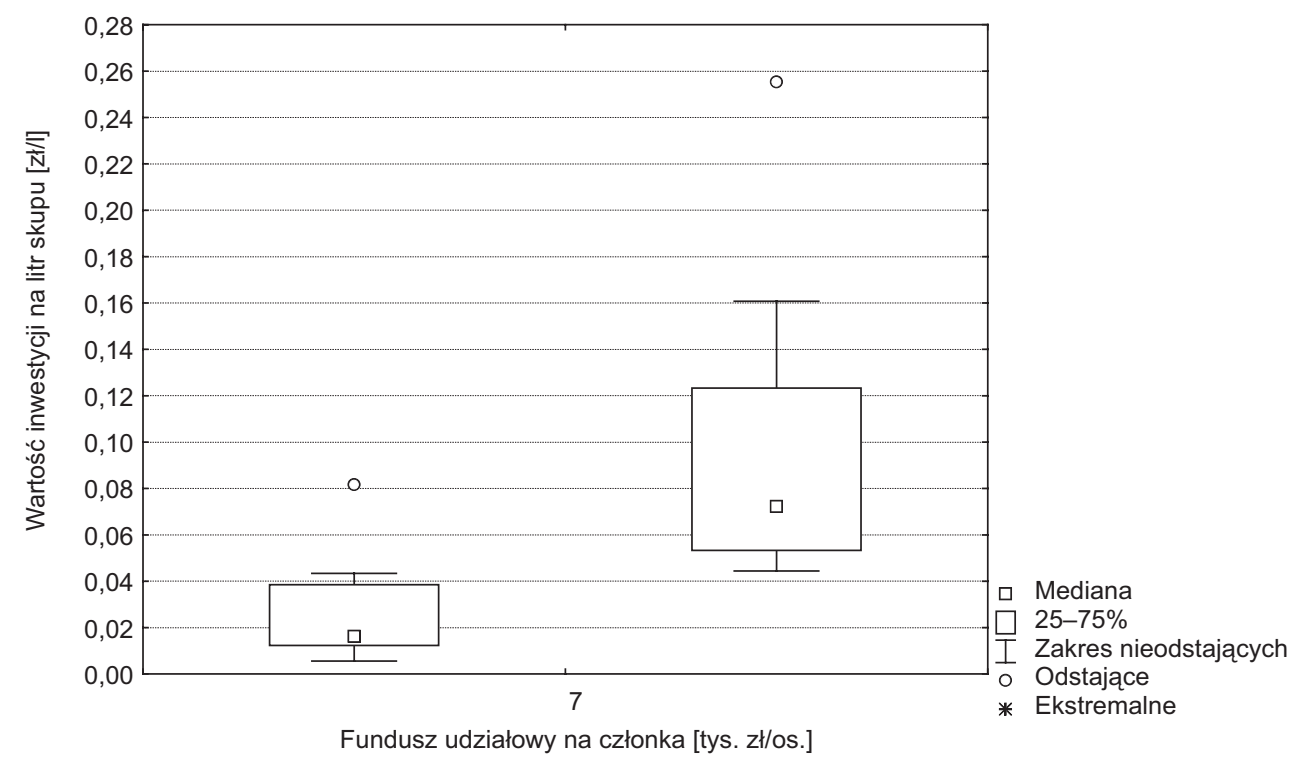

\section{Rysunek 2}

Siła więzi członkowskich a intensywność inwestowania

Źródło: badania własne

\section{Tabela 2}

Nowoczesność majatku trwałego a wyniki ekonomiczno-finansowe - współczynniki korelacji Pearsona między wskaźnikami

\begin{tabular}{|l|c|c|c|c|c|}
\hline \multirow{2}{*}{ Zmienna objaśniająca } & \multicolumn{4}{|c|}{ Zmienne objaśniane } \\
\cline { 2 - 6 } & $\begin{array}{c}\text { Ekonomiczna } \\
\text { wydajność } \\
\text { pracy }\end{array}$ & $\begin{array}{c}\text { Udział eksportu } \\
\text { w sprzedaży } \\
\text { produktów }\end{array}$ & Spieniężenie & ROE & $\begin{array}{c}\text { Cena } \\
\text { skupu } \\
\text { mleka }\end{array}$ \\
\hline $\begin{array}{l}\text { Relacja aktywów trwa- } \\
\text { łych netto do aktywów } \\
\text { trwałych brutto }\end{array}$ & $0,56^{*}$ & 0,19 & $-0,10$ & $0,42^{* *}$ & $0,60^{*}$ \\
\hline
\end{tabular}

Uwaga: * - korelacje istotne statystycznie na poziomie $\alpha=0,05 ;{ }^{* *}-$ korelacje istotne statystycznie na poziomie $\alpha=0,10 ; n=18$.

Źródło: Badania własne. 
Następnie poddano weryfikacji czy - zgodnie z modelem oceny rankingowej - „modernizacja i rozbudowa majątku” wpływa na poprawę wydajności pracy, rozwój eksportu, zwiększenie „spieniężenia” mleka oraz wzrost wartości generowanej dla członków (por. rys. 1). Badanie przeprowadzono odrębnie dla wskaźnika nowoczesności majątku oraz dla wskaźników intensywności inwestowania.

Analiza wykazała praktycznie brak korelacji wskaźnika nowoczesności majątku (tj. relacji aktywów trwałych netto do aktywów trwałych brutto) z udziałem eksportu w przychodach ze sprzedaży produktów oraz „spieniężeniem” mleka. Wyraźną i istotną statystycznie korelację odnotowano natomiast w przypadku ekonomicznej wydajności pracy oraz ceny skupu mleka. Łagodząc pułap współczynnika $\alpha$ do 0,10 , za istotną statystycznie można uznać dodatkowo średnią siłę korelacji wskaźnika nowoczesności majątku ze stopą zwrotu z kapitału własnego (tab. 2). Dla zmiennych wykazujących najsilniejsze i istotne statystycznie korelacje (dla $\alpha=0,05)$ przygotowano dodatkowo wykresy skategoryzowane (rys. 3-4).

Granicą rozdzielającą lewą i prawą stronę rysunków 3-4 jest mediana wskaźnika nowoczesności majątku. Rysunki ilustrują prawidłowość, że w spółdziel-

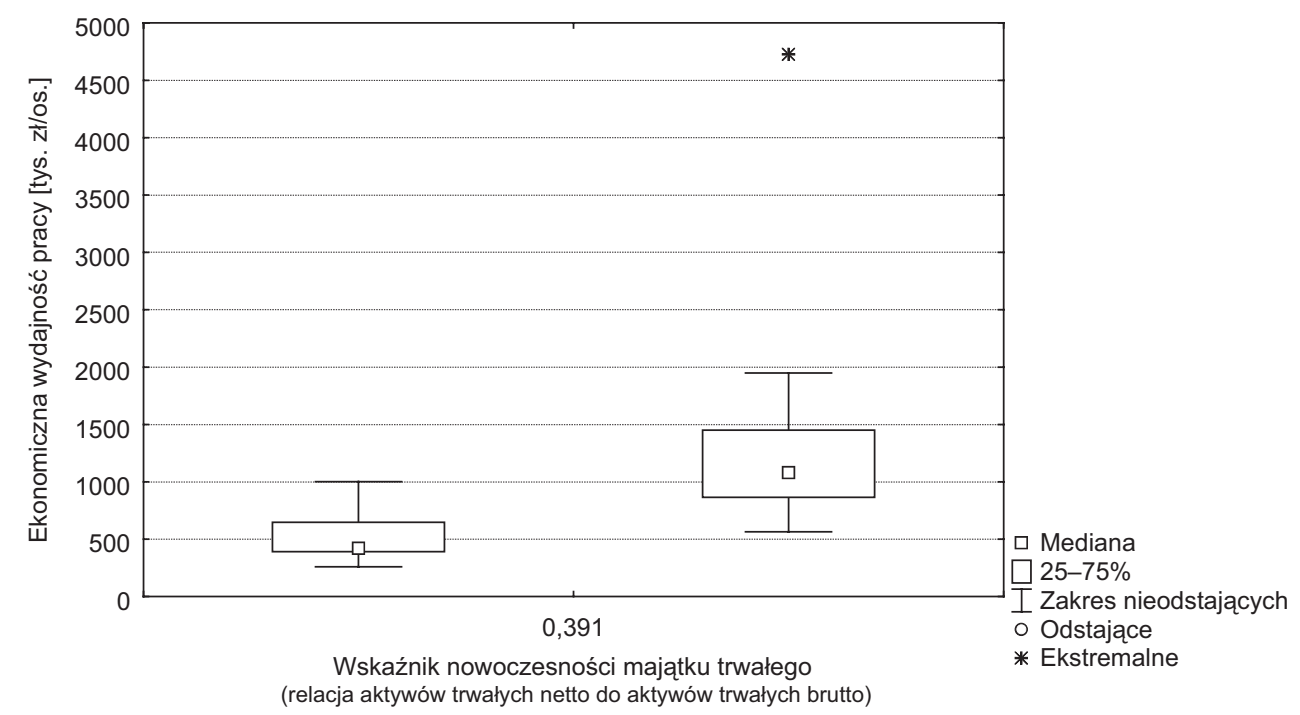

Rysunek 3

Nowoczesność majątku trwałego a wydajność pracy

Źródło: Badania własne. 


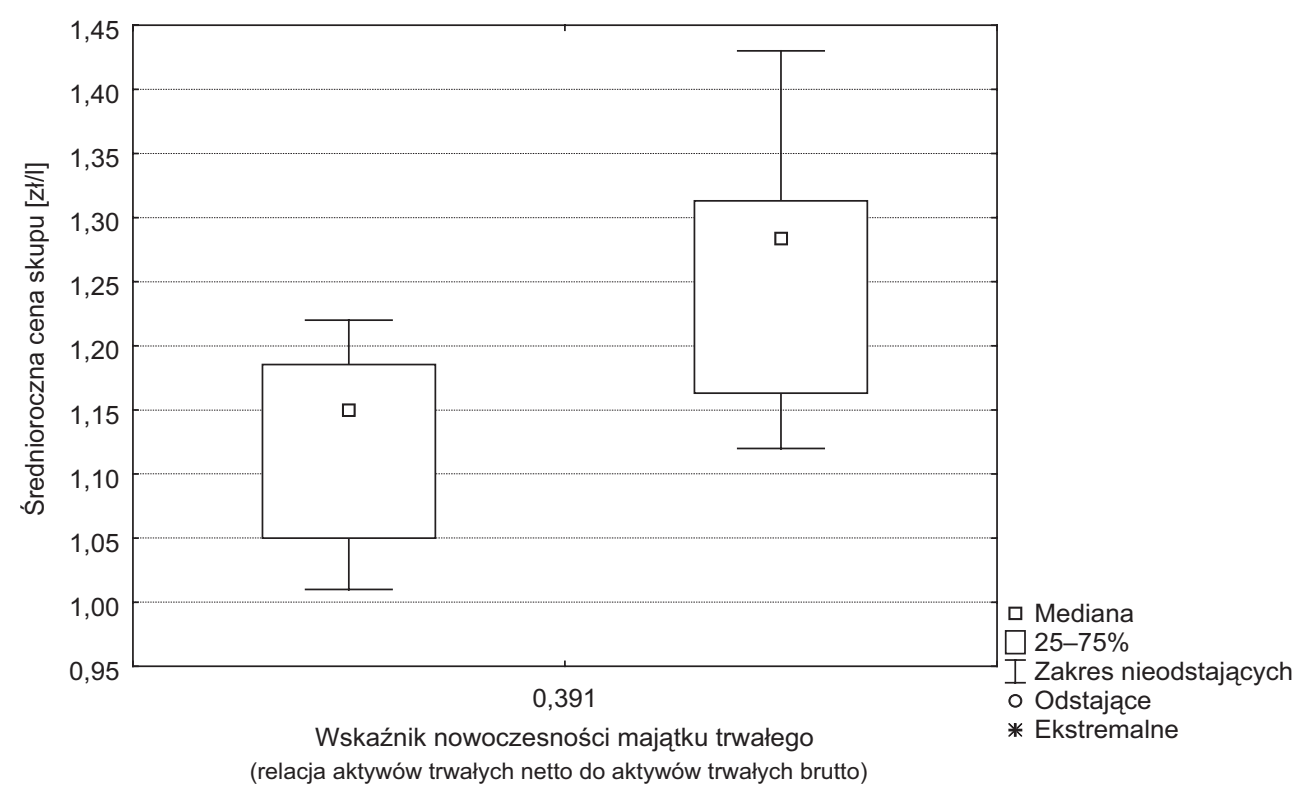

\section{Rysunek 4}

Nowoczesność majątku trwałego a cena skupu mleka

Źródło: Badania własne.

niach, w których wskaźnik ten przekracza medianę, tj. około $40 \%{ }^{6}$, wydajność pracy oraz cena skupu mleka jest wyraźnie wyższa.

Wydajność pracy w spółdzielniach o ponad $60 \%$ dekapitalizacji majątku trwałego nie przekracza 1000 tys. zł na osobę, a w ponad połowie $\mathrm{z}$ nich jest niższa niż 500 tys. zł na osobę. $Z$ kolei w grupie spółdzielni o niższej dekapitalizacji ponad połowa z nich przekracza pułap wydajności 1000 tys. zł na osobę (rys. 3). W połowie spółdzielni, w których wskaźnik nowoczesności majątku jest niższy od mediany (tj. 39,1\%), cena skupu nie przekracza $1,15 \mathrm{zł}$ za litr mleka, a wszystkie płacą rolnikom poniżej 1,23 zł/l. Z kolei w grupie spółdzielni o wyższej nowoczesności majątku ponad połowa $\mathrm{z}$ nich płaci powyżej $1,28 \mathrm{z}$ ł/1, a 1/4 z nich powyżej 1,31 zł/1 (rys. 4).

Analiza z uwzględnieniem wskaźników intensywności inwestowania wykazała praktycznie brak korelacji z udziałem eksportu w przychodach ze sprzedaży produktów - niezależnie od mianownika uwzględnionego we wskaźniku. Wskaźnik stopy zwrotu z kapitału własnego jest skorelowany na umiarkowanym poziomie ze wskaźnikiem nakładów inwestycyjnych do aktywów trwałych

\footnotetext{
${ }^{6}$ Co odpowiada około 60-procentowej lub mniejszej dekapitalizacji majątku trwałego.
} 
brutto (uzyskana korelacja jest istotna statystycznie przy „liberalnym” pułapie współczynnika $\alpha=0,10)$. Spieniężenie mleka jest skorelowane z nakładami inwestycyjnymi w relacji do funduszy własnych (średnia siła, istotność statystyczna dla $\alpha=0,10$ ) oraz nakładami inwestycyjnymi w przeliczeniu na litr skupu (średnia siła, istotność statystyczna dla $\alpha=0,05$ ). Najsilniejsza zależność korelacyjna wystąiła pomiędzy nakładami inwestycyjnymi w relacji do aktywów trwałych brutto a ekonomiczną wydajnością pracy (istotna statystycznie dla $\alpha=$ $=0,05)$. Z kolei największą liczbą istotnych statystycznie związków korelacyjnych ze wskaźnikami intensywności inwestowania cechuje się zmienna: cena skupu mleka. W dwóch wypadkach związki te można uznać za dość silne, przy istotności statystycznej dla $\alpha=0,05$ (nakłady inwestycyjne w przeliczeniu na litr skupu oraz nakłady inwestycyjne w relacji do przychodów ze sprzedaży), a w dwóch innych za umiarkowane, przy istotności statystycznej dla $\alpha=0,10$ (nakłady inwestycyjne w relacji do funduszy własnych oraz nakłady inwestycyjne w relacji do aktywów trwałych brutto) - tabela 3.

\section{Tabela 3}

Intensywność inwestowania a wyniki ekonomiczno-finansowe - współczynniki korelacji Pearsona pomiędzy wskaźnikami

\begin{tabular}{|c|c|c|c|c|c|}
\hline \multirow[b]{2}{*}{ Zmienne objaśniające } & \multicolumn{5}{|c|}{ Zmienne objaśniane } \\
\hline & $\begin{array}{c}\text { Ekonomiczna } \\
\text { wydajność } \\
\text { pracy }\end{array}$ & $\begin{array}{c}\text { Udział eksportu } \\
\text { w sprzedaży } \\
\text { produktów }\end{array}$ & Spieniężenie & ROE & $\begin{array}{l}\text { Cena } \\
\text { skupu } \\
\text { mleka }\end{array}$ \\
\hline $\begin{array}{l}\text { Nakłady inwestycyjne } \\
\text { w relacji do aktywów trwa- } \\
\text { łych brutto }\end{array}$ & $0,77^{*}$ & $-0,12$ & 0,11 & $0,46^{* *}$ & $0,45^{* *}$ \\
\hline $\begin{array}{l}\text { Nakłady inwestycyjne w re- } \\
\text { lacji do funduszy własnych }\end{array}$ & 0,22 & 0,05 & $0,48^{* *}$ & 0,13 & $0,49^{* *}$ \\
\hline $\begin{array}{l}\text { Nakłady inwestycyjne } \\
\text { w relacji do amortyzacji }\end{array}$ & 0,27 & $-0,01$ & 0,42 & 0,26 & 0,34 \\
\hline $\begin{array}{l}\text { Nakłady inwestycyjne } \\
\text { w relacji do przychodów ze } \\
\text { sprzedaży }\end{array}$ & $-0,04$ & 0,15 & 0,40 & $-0,05$ & $0,59^{*}$ \\
\hline $\begin{array}{l}\text { Nakłady inwestycyjne } \\
\text { w przeliczeniu na litr skupu }\end{array}$ & $-0,05$ & 0,13 & $0,50^{*}$ & $-0,08$ & $0,65^{*}$ \\
\hline
\end{tabular}

Uwaga: * - korelacje istotne statystycznie na poziomie $\alpha=0,05 ;{ }^{* *}$ - korelacje istotne statystycznie na poziomie $\alpha=0,10 ; n=16$ (braki danych usuwano przypadkami).

Źródło: Badania własne. 
Dla zmiennych wykazujących najsilniejsze oraz najliczniejsze i istotne statystycznie związki korelacyjne opracowano dodatkowo skategoryzowane wykresy typu ramka-wąsy (rys. 5-6). Granicami rozdzielającymi lewą i prawą stronę rysunków 5-6 są mediany odpowiednich wskaźników intensywności inwestowania. Rysunki te ilustrują wyraźną zależność pomiędzy intensywnością inwestowania a wydajnością pracy i ceną skupu w badanych spółdzielniach.

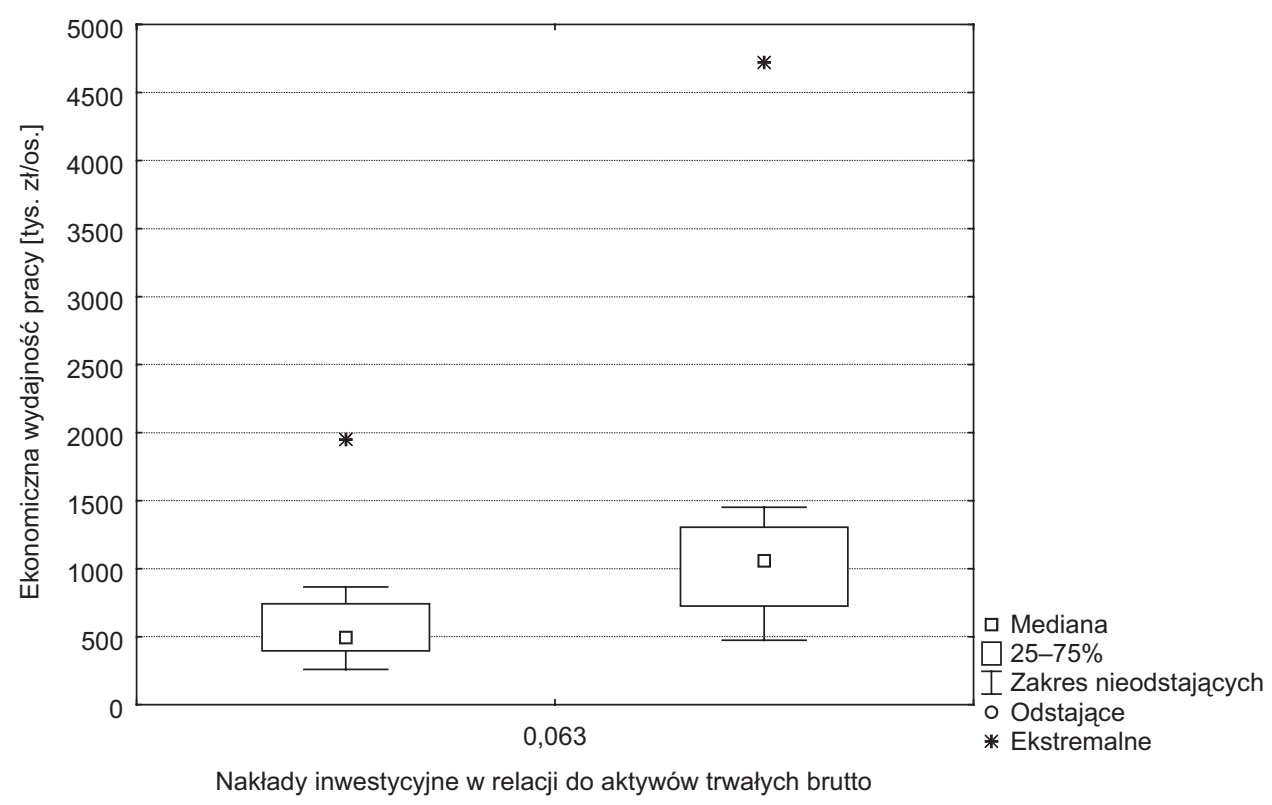

\section{Rysunek 5}

Intensywność inwestowania a wydajność pracy

Źródło: Badania własne.

W spółdzielniach, w których wskaźnik nakładów inwestycyjnych do aktywów trwałych brutto nie przekracza mediany, tj. 6,3\%, ekonomiczna wydajność pracy kształtuje się na przeciętnym poziomie 500 tys. zł na osobę, a pomijając obserwacje ekstremalne, najwyższa wydajność nie przekracza 900 tys. zł na osobę. Tymczasem w spółdzielniach o relacji nakładów inwestycyjnych do aktywów trwałych brutto powyżej 6,3\%, najniższa wydajność pracy odpowiada przeciętnej wydajności w grupie o niższej intensywności inwestowania, a mediana wydajności pracy to niemal 1100 tys. zł na osobę (rys. 5).

W połowie spółdzielni, w których wskaźnik inwestycji w przeliczeniu na litr skupu jest niższy od 4,9 groszy, cena skupu nie przekracza 1,16 zł za litr mleka, 
a wszystkie płacą rolnikom nie więcej niż 1,29 zł/1. Z kolei w grupie spółdzielni inwestujących więcej niż 4,9 groszy w przeliczeniu na litr skupionego mleka, ceny skupu są nie niższe niż $1,10 \mathrm{z} z / 1$, a ponad połowa $\mathrm{z}$ nich płaci powyżej 1,25 zł/1, a 1/4 powyżej 1,33 zł/1 (rys. 6).

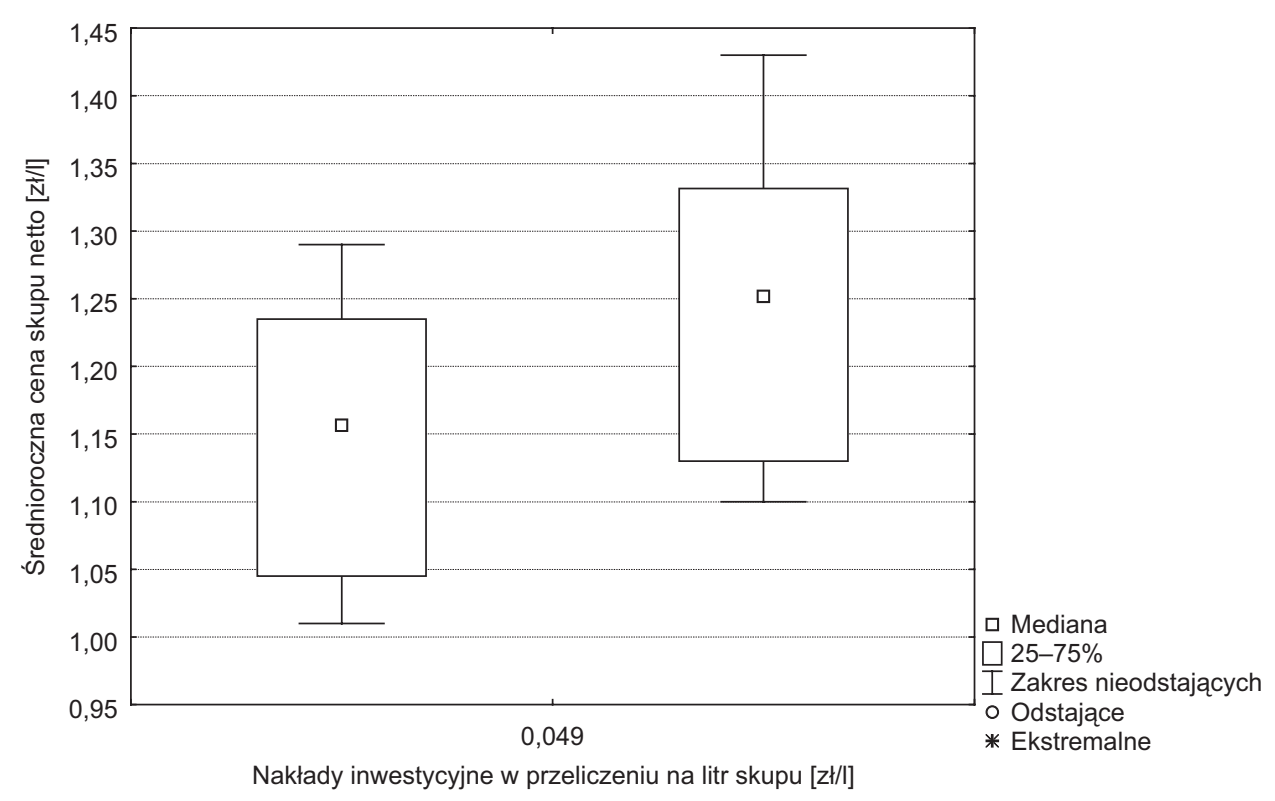

\section{Rysunek 6}

Intensywność inwestowania a cena skupu mleka

Źródło: Badania własne.

\section{Podsumowanie i wnioski}

Mapa strategii, która stanowi podstawę modelu oceny rankingowej spółdzielni mleczarskich (por. rys. 1) jest w istocie zbiorem hipotez strategicznych o zależnościach przyczynowo-skutkowych występujących pomiędzy poszczególnymi elementami modelu (celami). W niniejszym opracowaniu zweryfikowano założone w modelu zależności pomiędzy celem dotyczącym modernizacji i rozbudowy majątku (mierzonym z wykorzystaniem sześciu wskaźników) a wynikami ekonomiczno-finansowymi badanych spółdzielni.

Analiza korelacji potwierdziła występowanie związku między nowoczesnością majątku trwałego oraz intensywnością inwestowania a ekonomiczną wydajnością pracy, „spieniężeniem” mleka, ceną skupu mleka i rentownością 
funduszy własnych. Przy czym najsilniejsze i najliczniejsze zależności wystąpiły w przypadku ceny skupu i wydajności pracy. Słabsze i nie zawsze istotne zależności korelacyjne miały miejsce w odniesieniu do ROE i „spieniężenia” mleka. Nie potwierdziła się natomiast założona zależność między modernizacją i rozbudową majątku a udziałem eksportu w sprzedaży produktów. Uzyskane wyniki wskazują, że przedsięwzięcia inwestycyjne mogą być istotnym impulsem proefektywnościowym w spółdzielczych przedsiębiorstwach mleczarskich. Przedsięwzięcia te mają większą szansę na realizację w przypadku silniejszych więzi członkowskich, których praktycznym przejawem jest większe zaangażowanie finansowe członków w działalność spółdzielni.

Należy jednak pamiętać o ograniczonej liczebności obiektów badawczych, będących źródłem danych empirycznych do niniejszego opracowania. Stąd też, zważywszy na duże znaczenie praktyczne tego problemu, wskazane są dalsze badania nad wpływem inwestowania w majątek trwały na wyniki ekonomiczno-finansowe spółdzielni mleczarskich. Szczególnie pożądane byłyby badania na szerszej próbie badawczej oraz badania z uwzględnieniem szeregów czasowych, które pozwoliłyby uchwycić ewentualne przesunięcia w czasie efektów przedsięwzięć inwestycyjnych.

\section{Literatura}

BECKER B.E., HUSELID M.A., ULRICH D.: Karta wyników zarzqdzania zasobami ludzkimi, Oficyna Ekonomiczna, Kraków 2002.

BOULTON R.E.S., LIBERT B.D., SAMEK S.M.: Odczytujac kod wartości. Jak firmy tworza wartość w nowej gospodarce, WIG-Press, Warszawa 2001.

JAJUGA K., JAJUGA T.: Inwestycje. Instrumenty finansowe, aktywa niefinansowe, ryzyko finansowe, inżynieria finansowa, Wydawnictwo Naukowe PWN, Warszawa 2006.

KAPLAN R.S., NORTON D.P.: Strategiczna Karta Wyników. Jak przełożyć strategie na działanie, Wydawnictwo Naukowe PWN, Warszawa 2001.

KAPLAN R.S., NORTON D.P.: Strategy Maps: Converting Intangible Assets into Tangible Outcomes, Harvard Business School Press, Boston 2004.

PIETRZAK M.:, Efektywność finansowa spółdzielni mleczarskich - koncepcja oceny, Wydawnictwo SGGW, Warszawa 2006.

PIETRZAK M.: Balanced Scorecard - Zrównoważona Karta Wyników, [w:] Pietrzak M. (red.), Metody i techniki menedżerskie, Wydawnictwo SGGW, Warszawa 2007.

PIETRZAK M.: Sektor przetwórstwa mleka w Polsce, przemiany, stan obecny i perspekty$w y$, maszynopis referatu wygłoszonego na konferencji: Ekonomiczne i organizacyjne uwarunkowania produkcji mleka i żywca wołowego na świecie, w Unii Europejskiej i w Polsce, Warszawa, 20 września 2012.

PIETRZAK M., BARAN J.: Dodatek metodyczny V rankingu spółdzielni mleczarskich oraz oceny metoda DEA, [w:] Polska spółdzielczość mleczarska w Unii Europejskiej-szanse 
i zagrożenia, IX Forum Spółdzielczości Mleczarskiej: Augustów, 29 września - 1 października 2011, Białystok 2011.

PLUTA W.: Planowanie finansowe w przedsiębiorstwie, Polskie Wydawnictwo Ekonomiczne, Warszawa 1999.

SIERPIŃSKA M., JACHNA T.: Ocena przedsiębiorstwa wedtug standardów światowych, Wydawnictwo Naukowe PWN, Warszawa 1997.

TYRAN M.R.: Wskaźniki finansowe, Oficyna Ekonomiczna, Kraków 2004.

\title{
Investments in fixed assets and economic performance of dairy cooperatives
}

\begin{abstract}
Even in the knowledge-based economy era tangible assets still matters. It is because the value of intangible assets steams from the combined bundle of both tangible and intangible resources. Therefore it is important issue to assess how investments in fixed assets are connected with business performance. This problem seems to be particularly interesting in the case of Polish dairy industry. It is important part of European and Polish agribusiness system. During transition in Poland a lot of investments in dairy industry were already done. There is substantial overcapacity noticed in this sector. However empirical evidence done on 18 Polish dairy cooperatives shows the positive correlation between modernity of fixed assets and intensity of developing them and economic performance of dairies.
\end{abstract}

